\title{
Early texts on the Cenozoic fossils of Aquitaine (1622-1767) and pioneering debates on the organic origin of fossils, the superpositioning of strata and the mobility of the seas
}

\author{
Gaston Godard* \\ Université Paris-Diderot, IPGP, UMR 7154 CNRS, 1 rue Jussieu, Paris 75238, France
}

Received: 5 January 2018 / Accepted: 17 April 2018

\begin{abstract}
Several unpublished or little known writings from the $17^{\text {th }}-18^{\text {th }}$ centuries deal with the Bordeaux region's "figured stones", which are actually Miocene fossils. The oldest work is a book by Pierre de L'Ancre (1622), where the author describes the shelly sediments of Sainte-Croix-du-Mont and relates Louis XIII's visit there in October 1620. De L'Ancre is unsure as to the origin of the fossil shells, which could be ascribed to consolidation of the host sediments during lengthy ages after a withdrawal of the sea, transport from the Ocean by the Flood or in-situ development through «esbatement de la nature» (i.e., a freak of nature). His text is remarkable for its description of the layers, which the author names «estages » (i.e., stages) and describes from the bottom up, suggesting that he grasped the principle of superposition later developed by Steno (1669). A later manuscript, kept at the Arsenal Library in Paris, was written between 1631 and 1673 by an unknown author: entitled Reflections sommaires sur quelques pierres de la Terre de Sales. It deals with the origin of the fossils in the shelly sands of Salles, south of Bordeaux. The author prefers the hypothesis of in-situ development in soil rather than an organic marine origin, thus remaining faithful to the "freaks of nature" thesis frequently accepted at the time. In the $18^{\text {th }}$ century, the Bordeaux Academy discussed the origin of these fossils. In 1718, Father Jules Bellet and Isaac Sarrau de Boynet studied the shells of Sainte-Croix-du-Mont; they suggested an organic origin in view of the scar left by the adductor muscle on the shells and the effervescence of the latter in vinegar. Sarrau de Boynet, however, refused to admit that the sea had reached this village and adopted the extravagant thesis of an anthropic accumulation of oysters, which Montesquieu approved only reluctantly. From 1745 on, Jacques-François Borda d'Oro began the study of Eocene sites and fossils in the Dax region; the observation of Lithophaga, incompatible with a transport by the Flood, reinforced him in his conviction of a marine origin. Nicolas Desmarest observed fossils in 1761, in particular near Saint-Émilion, and was convinced of their marine origin. In 1743 and 1745, the Bordeaux Academy organized essay competitions on the origin of the "figured stones". The candidates were in favour of the organic origin, but ignored the shelly sediments of the region. One of these candidates, Pierre Barrère, surprisingly states the principle of uniformitarianism as early as 1745. These writings, among the first devoted to the geology of the Aquitaine Basin, illustrate that certain basic elements of modern palaeontology and stratigraphy were already grasped in the $17^{\text {th }}$ and $18^{\text {th }}$ centuries.
\end{abstract}

Keywords: history of geology / principle of superposition / uniformitarianism / origin of fossils / Miocene / Aquitaine (France)

\begin{abstract}
Résumé - Premiers écrits sur les fossiles cénozoïques d'Aquitaine (1622-1767) et débats précurseurs sur l'origine organique des fossiles, la superposition des strates et la mobilité des mers. Plusieurs écrits des $17^{\mathrm{e}}$ ou $18^{\mathrm{e}}$ siècles, inédits ou peu connus, traitent des «pierres figurées » de la région bordelaise - en réalité, des fossiles miocènes. Le plus ancien est un mémoire inclus dans les Advertissemens d'un livre de Pierre de L'Ancre (1622), où l'auteur décrit le gisement de faluns de SainteCroix-du-Mont et relate la visite qu'y fit Louis XIII en octobre 1620. De L'Ancre s'interroge sur l'origine des coquilles et des sédiments, hésitant entre un ancien séjour de la mer suivi d'une consolidation «par de longs siècles », un transport par le Déluge depuis l'Océan et une formation in-situ par « esbatement de la nature ». Son texte est par ailleurs remarquable par la description des couches, que l'auteur nomme
\end{abstract}

*Corresponding author: godard@ipgp.fr 
«estages » et décrit de bas en haut, ce qui suggère qu'il percevait le principe de superposition que Sténon (1669) n'avait pas encore énoncé. Un manuscrit plus tardif, conservé à la Bibliothèque de l'Arsenal à Paris, fut rédigé entre 1631 et 1673 par un auteur inconnu. Intitulé Reflections sommaires sur quelques pierres de la Terre de Sales, il traite de l'origine des faluns de Salles, au sud de Bordeaux. L'auteur y privilégie l'hypothèse d'une génération in-situ dans le sol plutôt qu'une origine organique marine, et demeure ainsi fidèle à l'hypothèse des « jeux de la nature » encore majoritairement admise. Au $18^{\mathrm{e}}$ siècle, l'Académie de Bordeaux s'empare du débat sur l'origine de ces fossiles. En 1718, l'abbé Jules Bellet et Isaac Sarrau de Boynet étudient les faluns de Sainte-Croix-du-Mont et se rangent à une origine organique, démontrée selon Boynet par l'empreinte laissée par le muscle adducteur sur les coquilles et par l'effervescence de celles-ci au vinaigre. Sarrau de Boynet se refuse toutefois à admettre que la mer ait pu atteindre ce lieu et adopte la thèse extravagante d'un amoncellement anthropique d'huîtres, que Montesquieu n'approuve qu'avec réticence. À partir de 1745, Jacques-François Borda d'Oro entreprend l'étude des terrains et fossiles (éocènes) de la région de Dax ; l'observation de lithophages, incompatibles avec un apport par le Déluge, le conforte dans sa conviction d'une origine marine. Nicolas Desmarest, qui a observé des fossiles lors de deux voyages entrepris en 1761 en Guyenne, notamment dans les environs de Saint-Émilion, puis en Périgord et en Gascogne, ne doute pas de leur origine marine. En 1743 puis 1745, l'Académie de Bordeaux organise des concours de dissertation sur l'origine des pierres figurées. Les candidats se prononcent pour l'origine organique, mais méconnaissent les faluns de la région et s'en tiennent à des généralités. L'un d'eux, Pierre Barrère, nous surprend en énonçant le principe d'uniformitarisme dès 1745. Ces écrits, parmi les premiers consacrés à la géologie du Bassin aquitain, illustrent que certains concepts de base de la paléontologie et de la stratigraphie modernes étaient déjà perçus aux $17^{\mathrm{e}}$ et $18^{\mathrm{e}}$ siècles.

Mots clés : histoire de la géologie / principe de superposition / uniformitarisme / origine des fossiles / Miocène / Bassin aquitain

In the $17^{\text {th }}$ century the thesis of the organic origin of fossils, then called "figured stones", was still unable to convincingly explain their puzzling presence in places distant from the sea. A number of scholars living in Bordeaux (France), confronted with the extraordinary abundance of fossils in the Miocene faluns (i.e., shelly sediments) of Sainte-Croix-du-Mont and Salles, in Guyenne, debated this question. We here present several unpublished or little known memoirs on the Guyenne fossiliferous faluns, such as those of Pierre de L'Ancre (1622), various members of the Bordeaux Academy (1718-1767) and Nicolas Desmarest (1761), before tracing the evolution of the ideas they reveal.

\section{Pierre de L'Ancre teaches Louis XIII a lesson on geology (1622)}

Pierre de Rosteguy de L'Ancre (1553-1631), a counsellor at the Parliament of Bordeaux, is known for his books on demonology (L'Ancre, 1612, 1617, 1622, 1627) and for having persecuted and sent the alleged witches of Labourd (Basque Country) to the stake (e.g., Communay, 1890; Français, 1910, p. 150-159). In order to convince the sceptics of the merits of his policy of terror against witches, in 1622 he published L'incredulité et mescreance du sortilege plainement conuaincue, a book that has become very rare today (L'Ancre, 1622; see Climens, 1884) (Fig. 1; cf. Appendix A1). With the exception of the professor of agriculture Auguste Petit-Lafitte $(1846,1867)$, naturalists and geologists have paid no attention to this book, although its Advertissemens contain one of the earliest-if not the first-geological memoirs on the Aquitaine, devoted to the famous fossil oyster deposit of Sainte-Croix-duMont (Fig. 2). Although this topic was totally extraneous to the subject matter of the book, the author addressed it just because he was proud that King Louis XIII, to whom the book is dedicated, had visited the oyster deposit at his house of Loubens two years earlier. Although very disappointed to have been away at the time, Pierre de L'Ancre was obsequious enough to put on display a "Prayer for the King" in the NotreDame's chapel at Loubens (Communay, 1890, p. 34-35) (see Fig. 3).

In twenty-five pages interspersed with many digressions, the author describes the shelly sediments - now known to be Miocene - that crop out on the hillside of Sainte-Croix-duMont, located on the right bank of the Garonne, $40 \mathrm{~km}$ southeast of Bordeaux (L'Ancre, 1622, p. 17-42 of Advertissemens). There Pierre de L'Ancre owned the estate of Loubens, comprising a troglodyte chapel dug in the famous level of fossil oysters (Fig. 3). He describes «huistres [oysters...], coquillages [shells...], langues de serpent [Glossopetrae, i.e. shark teeth: Fig. 4], \& limaçons à plusieurs retortillons [gastropods] ». He recounts the visit that Louis XIII and his brother Gaston d'Orléans made to this deposit on their way to Béarn at the beginning of October 1620.

Pierre de L'Ancre wonders about the origin of these oysters. He is undecided between a transport by the biblical Flood and an in-situ generation through a freak of nature («esbatement de la nature»), while also considering that marine sediments which emerged through movements of the sea could have consolidated over lengthy ages («par de longs siecles », p. 35). He writes: "we see [...] the seas which are in perpetual agitation, some withdrawing, others flooding, and the shape of innumerable sites undergoing change" («nous voyons tous les iours croistre les Montagnes \& Rochers, \& les lieux fossoyez $\&$ creusez se remplir d'eux mesmes, $\&$ d'autres se diminuer \& changer: Et les Mers qui sont en perpetuelle agitation, les vnes se reculer, les autres inonder; \& la face d'vne infinité de lieux se diuersifier», p. 35). He cites many ancient writers, more to display his Classical culture than to enlighten the debate, and reports on observations made while 


\section{L'INCRE D VI.I'TE' E. $T$ MESCREANCE DV SORTILEGE $P$ L A I N E M E N T C ON VAIN CIVE.} traißté, de la verité ou lllufion dus Sortilege, de la Fafcinátion, de l'Attouchement, du Scopelifme, de la Diuination, de ta Lathature ou Liailon Magique, des Apparitions: Et d'vne infinité d'autres sares \& nouueaux fubjects.

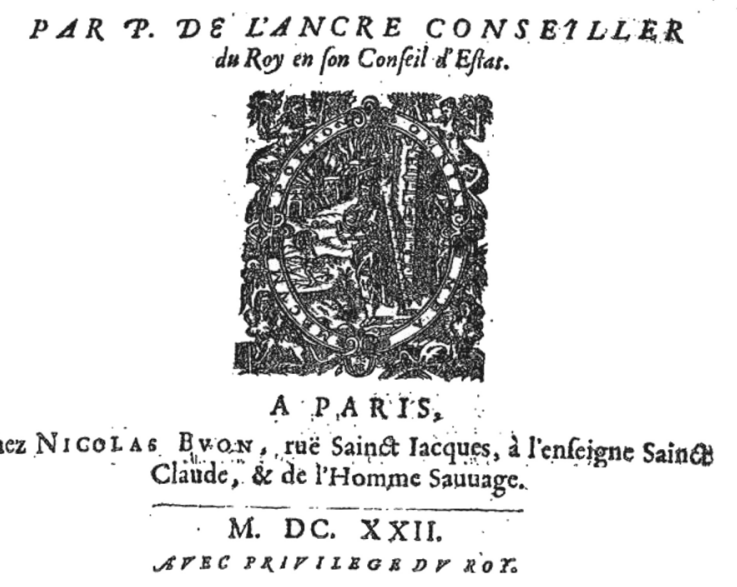

APEC PAIVIIEGBDDROT second estage allant à mont, est d'vn Coquillage en forme de petits limassons entortillez, que Tertullien appelle Buccinae»). These small "twisted" gastropods could be Potamides, very abundant in sandy clays of the Aquitanian (Lower Miocene), which pass to sandstones rich in numerous internal moulds of lamellibranchs and especially of gastropods (Potamides). Pierre de L'Ancre probably observed this facies along the path below the Loubens cliff (e.g., $44^{\circ} 35^{\prime} 25.1^{\prime \prime} \mathrm{N} ; 0^{\circ} 16^{\prime} 40.5^{\prime \prime} \mathrm{W} ; 1$ in Fig. 2). This path is edged with springs formed in relation to the underlying clay levels (e.g., $44^{\circ} 35^{\prime} 26.9^{\prime \prime} \mathrm{N} ; 0^{\circ} 16^{\prime} 45.8^{\prime \prime} \mathrm{W}$; 2 in Fig. 2). De L'Ancre recalls that Louis XIII walked along this "alley of fountains", where "there is still another kind of smaller shells that differ completely" from the oysters of the highest levels;

- "Above, there is another layer of hard stone: and afterwards there is a great cliff" («Au dessus il y a encore vne couche de Pierre dure: \& apres se trouue une grande leuée»). Upslope there is a fifteen metre-thick cliff with metre-sized strata of cross-bedded calcareous sandstone (Fig. $5 \mathrm{~b} ;$; e.g., $44^{\circ} 35^{\prime} 30.7^{\prime \prime} \mathrm{N} ; 0^{\circ} 16^{\prime} 51.3^{\prime \prime} \mathrm{W} ; 3$ and 4 in Fig. 2) that is rich in Ostrea and contains Scutella bonali and Amphiope ovalifera of the Burdigalian (Lower Miocene);

- then comes "a third stage of other piled up oysters" ( « vn troisiesme estage d'autres Huistres amoncellées ») representing the famous oyster bed of the Burdigalian (Lower Miocene), which is very rich in Ostrea aquitanica Mayer and can reach 4 meters in thickness (Fig. 5a; e.g., 5 and 6 in Fig. 2). Some cellars and caves under the church and the castle of Sainte-Croix-du-Mont were dug in this level, as well as the troglodyte chapel visited by Louis XIII at Loubens (Fig. 3; ca. $44^{\circ} 35^{\prime} 27.5^{\prime \prime} \mathrm{N} ; 0^{\circ} 16^{\prime} 45.4^{\prime \prime} \mathrm{W}$; near 2 in Fig. 2);

- "And still above, almost at the top of the rough boulders, [...] there are big oyster shells attached" («Et encores au dessus \& presque au sommet des pieces de Rocher scabreuses, [...] il y a de grandes Escailles [d'huistres] attachées »). The roof of the caves is indeed made of a hardened layer inlaid with oysters and crowning the cliff.

touring Italy between 1574 and 1579, during which he visited Calabria, Naples, Florence, Ravenna and Venice. After lengthy discussion and numerous caveats, he still comes to no definitive conclusion.

The text is mainly worthy of note for the passage (p. 40) in which the author describes the sequence of layers: he enumerates them from bottom to top and names them « estages» (i.e., stages). This kind of geological cross-section was surveyed at Loubens, where an embankment some 25 metres high is crowned by the famous fossil oyster level and extends north-westwards as far as Sainte-Croix-du-Mont (up to 6 in Fig. 2). De L'Ancre's description is precise enough to assign these "stages" to the various formations described by modern geologists (e.g., Alvinerie and Dubreuilh, 1978):

- "The base and foot of the Rock is of hard stone" («La base $\&$ pied du Rocher est de pierre dure \& nette sans autre meslange»). This could be a fluvio-lacustrine limestone with traces of Planorbis ascribed to the Upper Oligocene. Below this "rock", the Oligocene is represented by marls and clays, resulting in a more gentle topography with meadows and vines;

- "The second stage going uphill, is of a shell in the form of small twisted snails, which Tertullian calls Buccinae" («Le

\section{The "summary reflections" on the stones of Salles (circa 1650)}

The second text, more recent but actually more archaic in terms of ideas, is an unpublished manuscript entitled Reflections sommaires sur quelques pierres de la Terre de Sales. This document, stored in the Philibert de La Mare's collection at the Arsenal Library in Paris (see Appendix A2), describes the Neogene formations and Miocene fossils around Salles, some $45 \mathrm{~km}$ southwest of Bordeaux and $50 \mathrm{~km}$ west of Sainte-Croix-du-Mont.

The manuscript is anonymous and undated, but it was likely written between 1631 and 1673 , since it mentions Arnaud de Pontac as president of the Bordeaux Parliament (Pontac was appointed president à mortier in 1631 and First Mare's collection, the Reflections sommaires are preceded by another manuscript dealing with the fossils of the Montagne de Rheims (Champagne) that was written by the Jesuit Jacques president from 1653 to 1673: Le Mao, 2007). In Philibert de La 


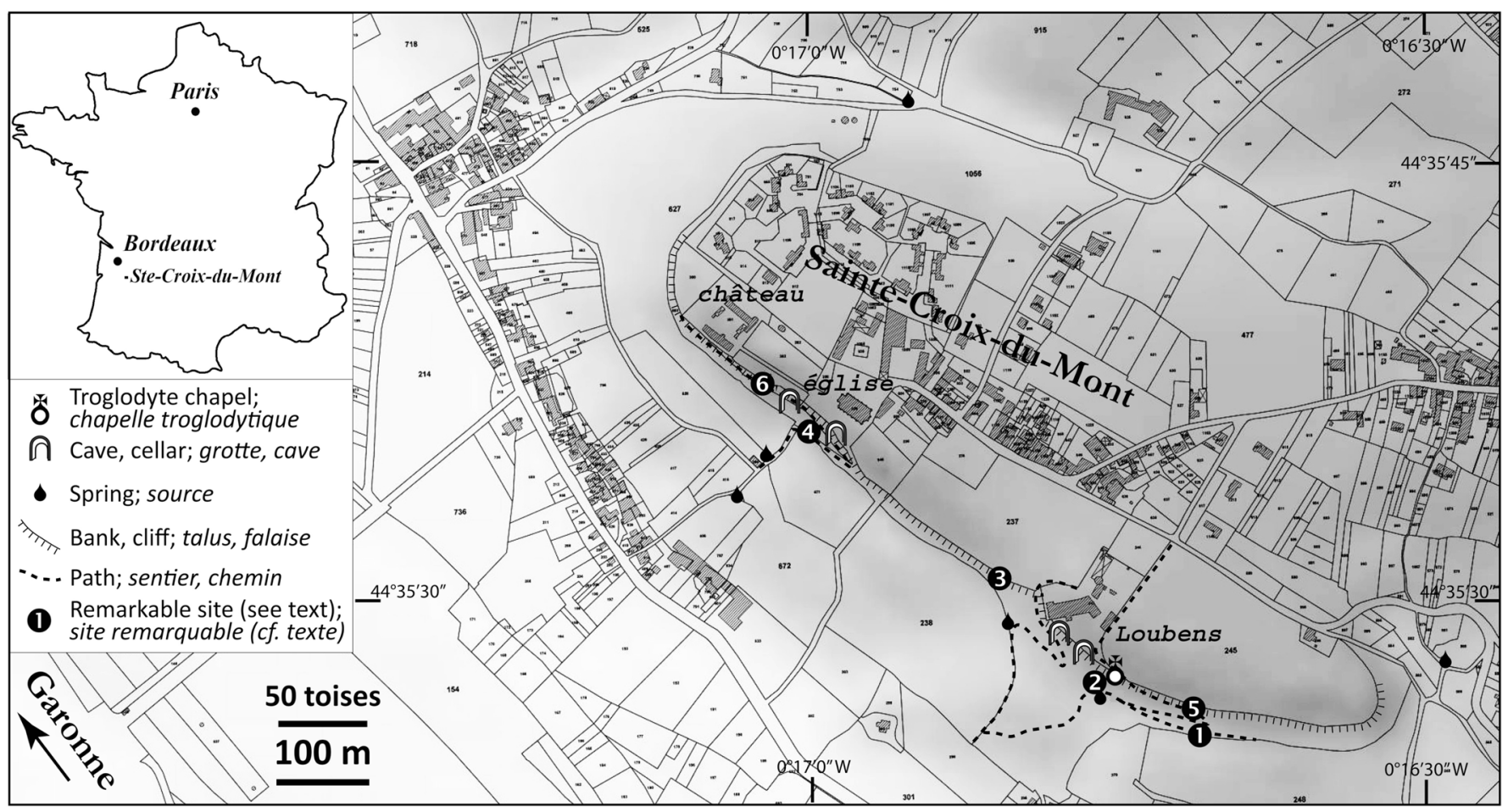

Fig. 2. Map of Sainte-Croix-du-Mont.

Cadastral plan and digital elevation model from Institut géographique national (@IGN).

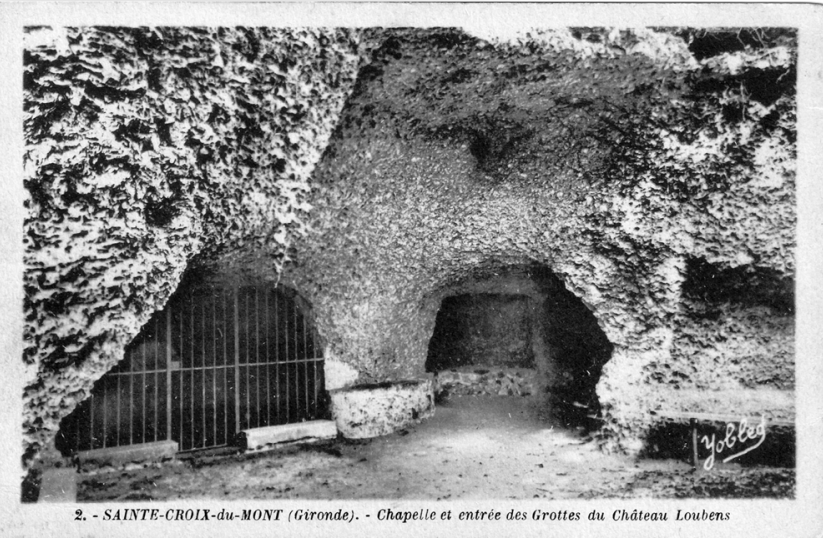

Fig. 3. Troglodyte Chapel of Loubens, visited by Louis XIII in 1620. The chapel was dug in the Burdigalian oyster level, the base of which is about $40 \mathrm{~cm}$ above ground level; postcard of the early $20^{\text {th }}$ century. The "Prayer for the King" (i.e., Louis XIII) has apparently been removed.

Vignier in around 1655 (Godard, 2014, 2017). Although these two manuscripts belong to the same portfolio, the differences in style and scientific ideas indicate that they are not by the same author. We do not know how these manuscripts were acquired by the bibliophile and historian Philibert de La Mare (1615-1687), who was a counsellor at the Burgundy Parliament in Dijon. His collection was acquired by the French Royal Library under the Regent Philippe d'Orléans, and was later transferred to the Arsenal Library in Paris (Muteau and Garnier, 1858-1860, vol. 2, p. 21).

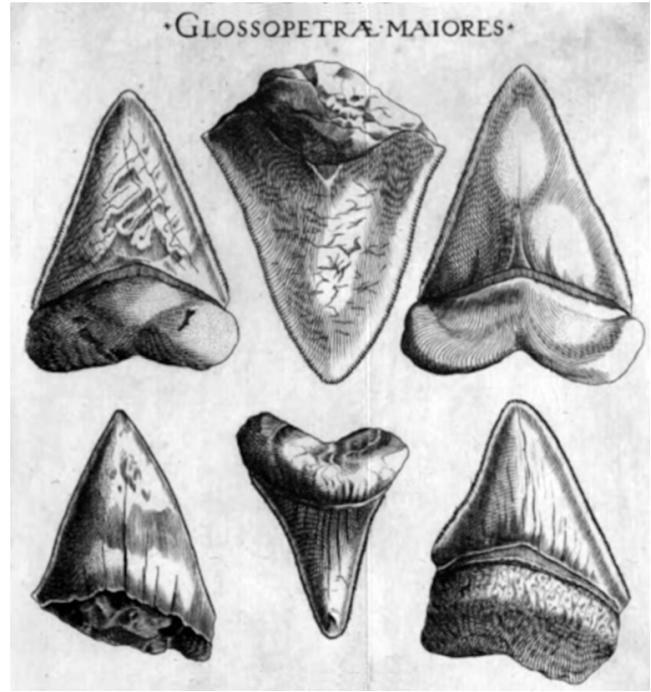

Fig. 4. Glossopetrae according to Steno (Steensen, 1667). Steno demonstrated that the Glossopetrae are in fact fossil shark teeth.

The author of the manuscript describes the fossiliferous sandstones that crop out in the Eyre Valley, near Salles (Guyenne, now in Gironde), under the Pleistocene cover of the Landes de Gascogne. What impressed him, as no doubt many observers before him, were the Serravalian shelly sandstones (Middle Miocene) of the banks of the Eyre (Fig. 5c; e.g., $44^{\circ}$ $32^{\prime} 57^{\prime \prime} \mathrm{N}$; $\left.0^{\circ} 52^{\prime} 21^{\prime \prime} \mathrm{W}\right)$, rich in abundant and varied fossil fauna (Platel, 1992). The description he gives, however, is very 

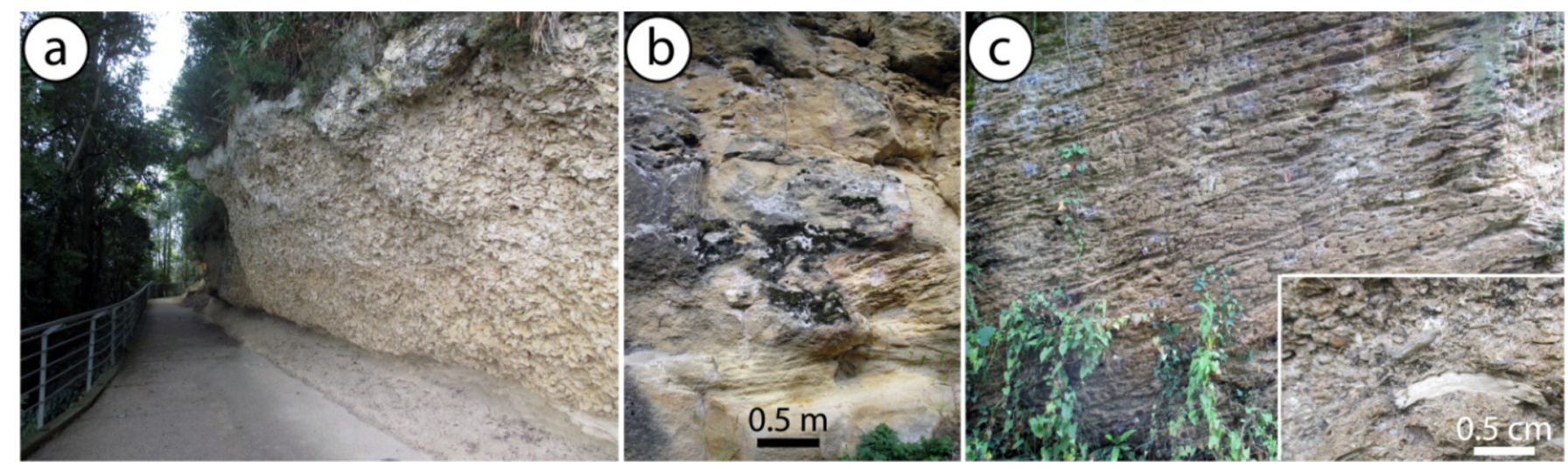

Fig. 5. Photographs of the fossiliferous sediments.

a: Burdigalian oyster level at Sainte-Croix-du-Mont (6 in Fig. 2); b: cliff made up of cross-bedded calcareous sandstone at Sainte-Croix-duMont (4 in Fig. 2); c: fossiliferous sandstone at Salles $\left(\mathrm{S}_{0}: \mathrm{N} 18^{\circ} \mathrm{W} 27^{\circ}\right)$.

poor. Among the fossils reported, there are cone-shaped "snails" (gastropods), "shells" (lamellibranchs) and "tongues of serpents" (Glossopetrae), which the author does not identify as shark teeth, unlike his contemporaries Colonna (1616) and Steno (Steensen, 1667) (Fig. 4). He also very succinctly describes the rocks of the region, mentioning some white marl («pierres [...] blanches et molles»), reddish sand («sable rougeastre $»)$, iron-rich stone («pierre mine de fer») and «alios», a sandstone typical of the Landes de Gascogne containing a cement rich in iron hydroxide.

The anonymous author focuses especially on explaining the presence of marine fossils in an area so far from the sea-Salles is located $30 \mathrm{~km}$ from the Ocean. He considers two contrasting hypotheses:

- a transport of the shells by the biblical Flood. According to the author, "it is against all likelihood" that "at the time of Noah the swelling Ocean pushed these shells onto this land" (que « au temps de Noë [...] l'ocean se desbordant ayt poussé ces coquilles jusques dans cette terre [...] c'est choquer la vraysemblance »). He has three objections to the Flood, formulated with more or less clarity: (i) he doubts "that these shells could have been preserved for so many centuries" after the Flood; (ii) he objects that "we sometimes only observe the imprint of their figure"; (iii) had they been carried by "the universal Flood", these shells would be equally abundant between Salles and the Ocean. Indeed, the Miocene sands and sandstones of Salles appear to be very fossiliferous, whereas the Pleistocene sands and gravels located farther west towards the Ocean are almost azoic;

- the second hypothesis, known as the "freaks of nature", denies the organic origin of fossils, which are considered to form spontaneously in-situ in the mass of rocks. The author, imbued with Aristotelian philosophy, gives his own version: these seashells "are formed from moisture in the soil through the influence of certain stars" («se forment d'une humidité de la terre exhausté par les influances de certains astres »). In his view, earth, one of the four classical elements of Empedocles and Aristotle, can generate these shells if it is moist rather than dry.

The author also expounds beliefs inherited from the medieval lapidaries and which are no longer relevant in the $17^{\text {th }}$ century. He names minerals and plants which, like the fossils, form spontaneously and take singular forms in order to be imbued with certain specific (alleged) properties. It is no coincidence that the "tongues of serpents" found in the soil - in actual fact fossilized shark teeth (Fig. 4)-are shaped like tongues: reduced to a powder, they are used in gargles for treating tongue diseases.

\section{The works of the Bordeaux Academy (1718-1767)}

At the beginning of the $18^{\text {th }}$ century, the Académie royale des belles-lettres, sciences et arts de Bordeaux began to debate the origin of the Sainte-Croix-du-Mont oyster shells (see also Courteault, 1909). A memoir on this deposit, sent by Jules Bellet, priest at Cadillac and founding member of the Academy, was read during the session of May 8, 1718 (Appendix A3.1). Father Bellet has no doubt that it consists of "marine oyster shells" and cites ancient and modern authors who have reported the presence of such shells inland; he is convinced that the sea was once present in the area and "left [the shells] here during its withdrawal". Based on the ancient texts, he states that in Roman times the shore was close to the present one, and that consequently the sea at Sainte-Croix-duMont dates back to the Flood, which he believes occurred 4115 years ago - the author covered the margins of his manuscript with numbers relating to this calculation. In the rest of the memoir, Father Bellet briefly describes some outcrops, recalls the visit of Louis XIII to Loubens and transcribes the "Prayer for the King" that Pierre de L'Ancre composed for the occasion.

Bellet's report excited the curiosity of the Academy. A note on the margins of his manuscript indicates that an excerpt of the memoir was sent to the Regent Philippe d'Orléans, together with a map drawn up by Barrelier de Bitry, chief engineer at the Bordeaux fortress of Château-Trompette. This map, entitled Vüe de la Coste de $S^{\text {te }}$ Croix du mont, is now stored at the Bibliothèque de l'Institut in Paris (Fig. 6; Appendix A3.5), but there is no trace of the associated memoir.

During the summer of 1718 , several members of the Academy travelled to Sainte-Croix-du-Mont, and on 25 August, 1718, Isaac Sarrau de Boynet read a new manuscript 


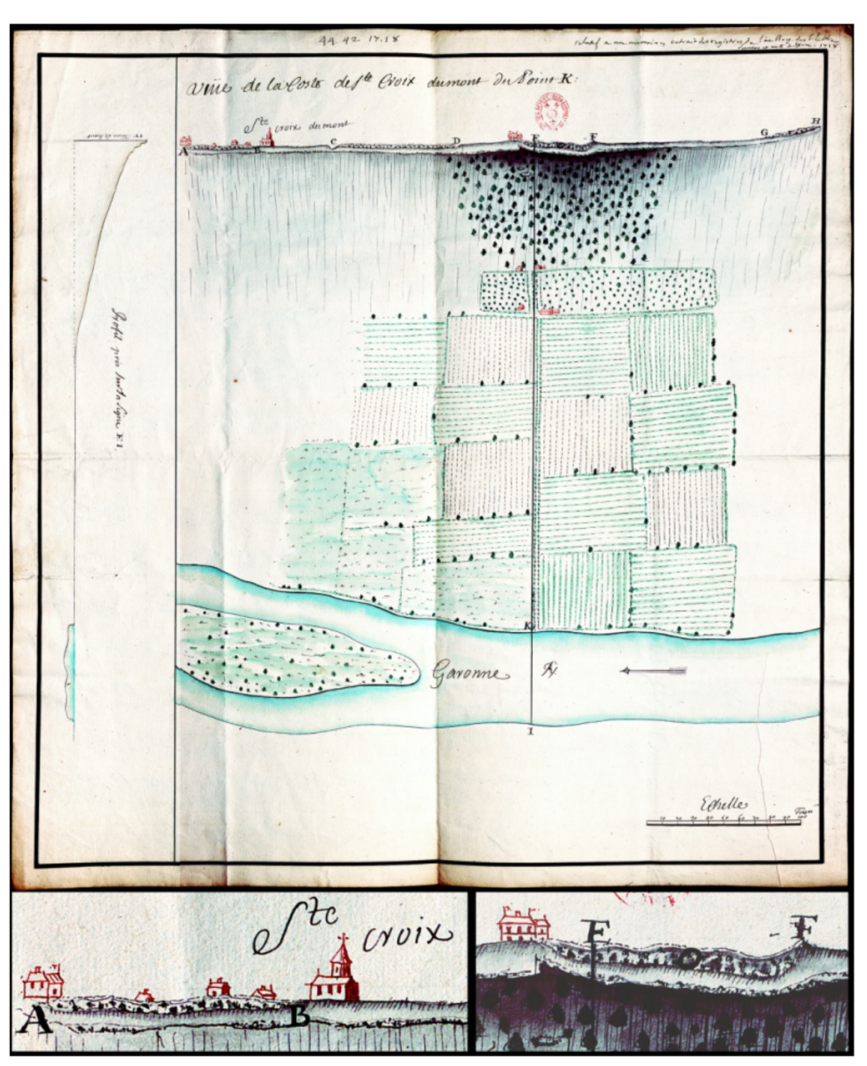

Fig. 6. «Vüe de la Coste de $S^{\text {te }}$ Croix du mont» (1718).

Map and perspective view by Barrelier de Bitry (1718), 51.5 $\mathrm{cm} \times 53.5 \mathrm{~cm}$ at a scale of $9.4 \mathrm{~cm}$ per 100 "toises" (ca. 1: 2100; 1 toise $\approx 1.95 \mathrm{~m}$ ), with topographic profile (left) from the River Garonne (I) to Loubens (E); details of the cliff at Sainte-Croix-duMont (bottom left) and Loubens (bottom right) are shown (CBibliotheque de l'Institut; see Appendix A3.5). The cliff is represented from the castle $(A)$ to its SE edge $(H)$, with a mottled pattern indicating the oyster-rich level (e.g., between $\mathrm{C}$ and $\mathrm{D})$. The letters refer to a missing memoir; A: castle; B: church; C: ravine (?); D, E, F: Loubens; "O": troglodyte chapel; K: access to "allée des pins", where Louis XIII landed in 1620.

on the subject before the Academy (Appendix A3.2 and A3.3). He described the outcrops and the "vein of shells" between two "hard stone beds". He also studied the fossil shells, noting their effervescence in vinegar and the scars left by the adductor muscle; from this he deduced that the fossils are similar to current marine shells. Convinced of the organic origin, Boynet hesitates between transport by the Flood and deposition by the sea, which was difficult to imagine given the altitude of the area. Lastly, he suggests that for some (admittedly obscure) reason, the men of antiquity could have transported the oysters to their present position. This extravagant thesis reflects Boynet's frustration with the incomprehensible. Montesquieu, who presided over the session, expressed apparent satisfaction: "When one cannot be sure of the truth," he declared, "it is good to have something that resembles it" (Appendix A3.4).

Father Jules Bellet continued to send to the Academy handwritten chronicles proudly entitled Voyages littéraires. That of 1736, devoted to the region of Sainte-Foy-la-Grande, reports that "in the parish of Fleix, on the hillside of Nogarède, a prodigious quantity of oyster shells has been found within layers of soft stone about 4 to 5 inches thick. In some pieces of a boulder that fell into the Dordogne River, one sees petrified scallops and sometimes imprints of other shells" (see Appendix A4.1 for the original text). The Nougarède deposit, located at Fleix on the right bank of the Dordogne (ca. $44^{\circ} 51^{\prime} 5$ 9.5" N; $0^{\circ} 14^{\prime} 20^{\prime \prime} \mathrm{E}$ ), is also known as Bois-du-Mignon. It was studied by Fallot (1887), who reported Ostrea longirostris in Upper Ludian clays (Late Eocene; likely Early Oligocene). "In the parish of Monfaucon, next to that of Fleix, at the place named Barbeyrole", continues Jules Bellet, "a quarry of hard stone has been opened, where one cannot detach a stone without finding attached a horn of Ammon, together with petrified oyster shells that still have their nacre. We have also found petrified shells with their natural colours". The rocks around Barbeyrolle ( $\left.44^{\circ} 52^{\prime} 55^{\prime \prime} \mathrm{N} ; 0^{\circ} 13^{\prime} 52^{\prime \prime} \mathrm{E}\right)$ belong to the Upper Eocene and Oligocene (Dubreuilh and Karnay, 1994), where it is indeed surprising to find "horns of Ammon" (i.e., ammonites), probably confused here with gastropods. Sarrau de Boynet presented Bellet's findings to the Academy. In his report (Appendix A4.2), Boynet compares these shells to those of Sainte-Croix-du-Mont and favours an organic origin, an opinion shared by Father Bellet, who however naively attributes the "horns of Ammon" to real petrified horns (A4.1).

Another member of the Academy of Bordeaux, Godefroy de Baritault, was especially concerned with fossils: he reportedly mentioned the rich deposit of Saucats in 1738 and undertook a methodical classification of shells and fossils from the Landes de Gascogne (Courteault, 1909), but we did not find evidence of these researches in the archives of the Academy.

Jacques-François Borda d'Oro (1718-1804), lieutenantgeneral of the presidial of Dax in Gascony (southern Aquitaine), was received corresponding member of the Academy on April 4, 1745, then full member on August 27, 1767 (Coste, 1908). He brought together a large collection of fossils and rocks of the Dax region (Desmarest et al., an III-1828, t. 3, p. 586; Odin and Zubillaga, 2005), to which he devoted important memoirs (Appendix A5.5) (Borda d'Oro, 1879-1881). These manuscripts, which he tried (in vain) to publish (Borda [d'Oro], 1798), are now stored at the Société Borda of Dax and have recently been studied by Odin (2004, 2005). Borda d'Oro also sent several memoirs on the same region to the Bordeaux Academy (Appendix A5.1-A5.4). In one of them, written in 1745 (A5.1), he describes the (Lutetian) sediments of Sorde-l'Abbaye and Nousse, six leagues S of Dax, that contain spiral fossils in the form of small "lentils [...] pierced with small holes" (i.e., Nummulites). Although "these bodies are totally unknown" to him, he likens them to "marine bodies" because they are associated with other shells, including a sea urchin. In 1767, Borda d'Oro investigated for the Academy the (Eocene) fossils of Montfort-en-Chalosse, four leagues E of Dax. In this memoir (A5.2), he describes Lithophaga («dails ») in "a layer of white and chalky stone". Jean-Étienne Guettard of the French Académie des Sciences had already described Lithophaga and Madrepora found near Dax and sent to him by Borda d'Oro (Guettard, 1759, p. 330 $339+$ pl. I, Fig. 3-6 therein; see Coste, 1908). Borda d'Oro points up that such marine fossils cannot have been transported by the Flood, which reinforces his conviction of a marine origin.

In the middle of the $18^{\text {th }}$ century, the Academy of Bordeaux launched two essay competitions (see Courteault, 1909): the 
first, in 1743, on the "Origin and formation of figured stones which, internally as well as externally, have a regular and determined figure"; the second, in 1745, on the "Figured stones". None of the memoirs sent to the Academy mention the fossils of Guyenne or Gascony (Appendix A6). The postulants unanimously embrace the notion of an organic origin, but remain somewhat theoretical.

\section{The spirit of the Encyclopaedists}

Dezallier d'Argenville, one of the major contributors to Diderot's Encyclopédie, briefly evokes the fossils of SainteCroix-du-Mont in his Enumerationis fossilium (Dezallier d'Argenville, 1751, p. 53): "In a place called Sainte Croix du Mont, in front of the castle gates [i.e., between 6 and 4 in Fig. 2], a large oratory was dug into a cliff of oysters; the vault and pillars supporting it are constructed of the same material" (« in loco dicto Satte [sic] Croix du Mont, ex adverso portarum Castelli, facellum magnum in monticulo Ostreis composito incisum est: testudo \& columnae, quae eam sustentant, eâdem materiâ constructae sunt»).

Nicolas Desmarest, then working for the Bordeaux Intendant, wrote in 1761 a travel journal of two trips from Bordeaux to Périgueux and from Bordeaux to Agen (Appendix A7.1) (see Taylor, 1969, 1997). In this manuscript, Desmarest describes the (Cenozoic) sediments of these regions. He occasionally mentions fossil shells and « madrepores », to which he clearly gives a marine origin. In particular, he gives details on the silicified fossils of Chancelade near Angouleme (A7.1, p. 306316), and on the shelly sediments of Saint-Émilion (A7.1, p. 112-119), with their "madrepores", shells, sea urchins, etc., and where he observed crisscross stratification («des lits qui ne sont point horizontaux mais qui font une suite d'angles contenus les uns dans les autres $\gg$ ). Later, Desmarest reproduced some of these observations in his Encyclopédie méthodique (see Appendix A7.2), devoted to physical geography and geology (Desmarest et al., an III-1828; see Laboulais-Lesage, 2006).

The authors of the second half of the $18^{\text {th }}$ century had no doubt about the marine origin of fossils, explaining their presence in Aquitaine by some incursions of the Atlantic Ocean. However, the systematic study of the shelly sands and sandstones (called "faluns") of Aquitaine would begin later, in the 1830s with the start of modern geology, and in particular with the detailed work of Jean-Pierre Sylvestre de Grateloup (Lesport et al., 2012).

\section{A laboratory of ideas for the progress of geology}

The above writings echo some debates and pioneering ideas on the origin of fossils, the superpositioning of strata and the geological ages, which we present in this section.

\subsection{The origin of fossils: transport by the Flood, freak of nature or mobility of the seas?}

In the $16^{\text {th }}$ and $17^{\text {th }}$ centuries, there were two main opposing theses for the origin of fossils (e.g., Rudwick, 1972; Ellenberger, 1988). The thesis of the "freak of nature" or lusus naturae, which Pierre de L'Ancre beautifully names « esbate- ment de la nature », ascribes the origin of fossils to spontaneous generation from the rock mass; the second hypothesis, that of an organic origin, clashes with the remoteness of the sea and therefore requires (it is believed) transport of the shells. Pierre de L'Ancre (1622), like the entourage of Louis XIII (according to his reports), is undecided between the two theses. Although the author of the Reflections sommaires (ca. 1650; Section 2) and contemporaries such as Gaffarel (1629) continue to dwell on the thesis of the "freaks of nature", those in favour of an organic origin gradually become the majority. Fracastoro, Alessandri, Palissy and Cesalpino in the $16^{\text {th }}$ century, and then Colonna, Peiresc, Vignier, Menestrier and Gassend in the $17^{\text {th }}$ century, do not doubt the organic origin of fossils (e.g., Rudwick, 1972; Ellenberger, 1988; Godard, 2005, 2017). However, these authors do not always embrace the bold hypothesis of the presence of the sea inland: Bernard Palissy (1580) makes shells live in "receptacles" of fresh water ( $c f$. Ellenberger, 1988, p. 137-146; Plaziat, 2011) and Pierre Gassend (1658) in underground cavities filled with water. Most supporters of the organic origin suggest the Flood transported shells from the sea. Some were staunch diluvianists, whereas others have been qualified as "soft" or "hesitant" diluvianists (e.g., Ellenberger, 1988) because they were convinced of the marine origin of the fossils, and considered the Flood a convenient artifice accepted by all or even a concession to the prevailing opinion of the time.

In the early $17^{\text {th }}$ century, some proponents of the organic origin had the audacity to invoke sea-level fluctuations. This is the case of Claude Menestrier in around 1635 to explain the fossils of Monte Mario, near Rome, and of Peiresc, who suggested that vertical ground movements exhumed the fossils of Provence and submerged the amber of the Baltic (Godard, 2005). In this respect, Pierre de L'Ancre is quite innovative, since in 1622 he envisions sea mobility operating over "long centuries" instead of a transport by the Flood (L'Ancre, 1622, p. 35) (see Section 1), suggesting a dynamic evolution of the Earth: "we see the mountains and the rocks growing every day, and the depressions fill up (with sediments) by themselves".

With the contributions of Steno (Steensen, 1667), Woodward (1695) and Scheuchzer (1708), the thesis of an organic origin prevailed at the turn of the $18^{\text {th }}$ century. However, most of the authors still believe in a transport and deposit by the Flood (e.g., Gaudant, 2008). This is also the case in Aquitaine, where Father Bellet and Isaac Sarrau de Boynet, secretary of the Bordeaux Academy, do not doubt the organic origin of the shells of Sainte-Croix-du-Mont. In 1718, Sarrau uses the scar left by the adductor muscle on the inner side of the shells to demonstrate this origin, an argument subsequently used a few decades later by Jean-Étienne Guettard (1759) to demonstrate the organic origin of Eocene fossils in the Paris Basin. Whereas Bellet is a staunch diluvianist, Sarrau de Boynet resorts to an improbable anthropogenic origin.

In the course of the $18^{\text {th }}$ century, the Flood hypothesis was progressively dismissed. In 1767, Jacques François Borda d'Oro fully supported the deposition by the sea of (Eocene) fossiliferous sediments near Dax in Gascony, after having observed traces of Lithophaga, incompatible with a transport by the Flood. In 1761, Nicolas Desmarest did not doubt of the marine origin of the Aquitaine fossils, which he observed notably around Saint-Émilion (Appendix A7.1), describing them as "marine organisms" (« corps marins »). Later, in his 
Encyclopédie méthodique, he dismissed any geological implication of the biblical Flood (Desmarest et al., an III1828, vol. 3, article "Déluge", p. 606-615). The concept of marine transgression will eventually replace the Flood at the birth of modern geology in the early $19^{\text {th }}$ century.

\subsection{Principle of superposition}

In describing the rocks and fossils shown to Louis XIII at Loubens (Section 1), Pierre de L'Ancre (1622) uses the word « estage » (i.e., stage), well before it came to be used by Alcide d'Orbigny (1840-1867) to designate a chronostratigraphic division. Pierre de L'Ancre enumerates these stages from bottom to top, whereas Louis XIII and his entourage walked through them from top to bottom, suggesting that de L'Ancre grasped the principle of superposition and the chronological sequencing of the layers even before Nicolas Steno formally stated them in 1669 (Steensen, 1669). Unfortunately, Pierre de L'Ancre did not develop these basic concepts of modern stratigraphy, preferring to satisfy his nauseous obsession with witchcraft and witches.

\subsection{Chronology and principle of uniformity}

Many $17^{\text {th }}$ and $18^{\text {th }}$ century scholars adopted a short chronology constrained by their belief in the Flood. This was also the case in Aquitaine. In 1718, Father Bellet covered the margins of his manuscript on Sainte-Croix-du-Mont with calculations on the biblical chronology. Sarrau de Boynet attributes the same deposit to the "most remote antiquity", having dismissed the Flood in favour of an anthropogenic origin. The boldest thesis is once again that of Pierre de L'Ancre (1622, p. 35, 39), who envisions the in-situ deposition of marine sediments consolidated over prolonged ages after the retreat of the sea. The fact that he does not rely stubbornly on the Bible is unexpected for a judge who condemned many people to the stake for heresy and witchcraft.

Among the contributions to the essay contests of 1743 and 1745 at the Bordeaux Academy, four can be attributed to Pierre Barrère, since they contain elements published by this author (Barrère, 1746) (see details in Appendix A6.1). The first and fourth memoirs are two versions of the same unpublished manuscript, written in 1743 and revised in 1745. Barrère develops a cyclical evolution of the Earth, which prefigures Hutton's ideas: the seas are filled with sediments and become mountains under the effect of earthquakes and volcanism, and mountains are in turn eroded and then invaded by seas. Moreover, in the 1745 version the author introduces several formulations of actualism (p. 6, 17, 18; see A6.1 [iv]): e.g., "The cause having acted in past ages, as it acts in the present, and as it will act in future, the effect must have been in the past as it will be in the future" (p. 17).

The principle of uniformity is attributed to Lyell (1830 1833), who had nevertheless been preceded by several pioneers, including Steno (Steensen, 1669), Buffon (1749), Desmarest, Hutton... Uniformitarian thinking involves two distinguishable elements: (a) the geological agents operating in the past were the same as at present, and (b) they operated at slow rates during long spans of time. Early geologists accepted the first element far more readily than they agreed to the second, as many were disposed to think that geological agents might in the past have acted with high intensities rather than slow rates. The historians of geology usually distinguish such an actualistic approach from uniformitarianism in a strict sense (e.g., Hooykaas, 1963; Rudwick, 1972, chap. 4). Were Barrère's ideas truly uniformitarian or simply actualistic? He claimed in his 1745 manuscript that the geological agents operate during long spans of time («pendant une longue suite de siècles », p. 6; see A6.1 [iv]). However, like Pierre de L'Ancre some 120 years before, he did not amplify these interesting ideas; he just addressed them allusively in his 1746 book (Barrère, 1746), which Buffon nevertheless praised and quoted (Buffon, 1749, p. 596-599).

\section{Conclusions}

The $17^{\text {th }}$ and $18^{\text {th }}$ century memoirs on the fossils of Guyenne and Gascony (Aquitaine Basin, France), especially those of Sainte-Croix-du-Mont, echo the debates of the time on the origin of "figured stones"-what we call fossils. The authors were undecided between an organic origin with transport of the shells by the biblical Flood and an in-situ origin resulting from an "esbatement de la nature» (a freak of nature). However, a few authors endorsed original ideas and novel concepts. The most remarkable author is Pierre de L'Ancre, whose text (L'Ancre, 1622), although marred by his untimely digressions, envisages that seas are mobile and that sediment consolidation took place over "lengthy ages" after sea withdrawal; he also describes the superimposition of layers, which he calls "stages" (« estages »), suggesting that he grasped the principle of superposition even before Steno (Steensen, 1669). In 1718, Isaac Sarrau de Boynet, secretary of the Bordeaux Academy, demonstrated the organic origin of fossil oyster shells on the basis of the scar left by the adductor muscle. In 1767, Borda d'Oro agreed with the deposition by the sea of fossils from the Dax region in Gascony after having observed traces of Lithophaga. In 1761, Nicolas Desmarest was also convinced of the marine origin of the fossils of northern Aquitaine.

These writings on Aquitaine show us that the history of geology is more profuse than it might be thought. Besides wellknown persons, like Palissy, Steno, Woodward, Buffon, Hutton, Lyell and others, there were a number of humble scholars, whose contributions remained unpublished and unknown. After having languished in the shadows for centuries, their writings, which have been brought to light by the modern means of digitization, cataloguing and diffusion, can now be considered. This appears strikingly for Aquitaine. Very few books were devoted to the geology of the Aquitaine Basin before the $19^{\text {th }}$ century: one can only cite a few lines on the Saintonge by Bernard Palissy (1580), memoirs on mines (Puy, 1601; Gobet, 1779), some indications by Dezallier d'Argenville (1751) and Nicolas Desmarest's studies (Desmarest et al., an III-1828)... On the other hand, there is a profusion of manuscripts (see Appendix), which give us a new vision of this history.

Acknowledgements. The author sincerely thanks Jean-Claude Piaziat and Kenneth L. Taylor for their constructive reviews, Arabella Palladino for the revision of the English style, and Catherine Crônier for her editorial handling. 


\section{References}

Alvinerie J, Dubreuilh J. 1978. Carte géologique de la France (1/50 000), feuille Langon (852). Orléans: BRGM, carte en couleurs, $60 \times 90 \mathrm{~cm}+$ notice explicative par J. Alvinerie, J. Dubreuilh, B. Moussié, L. Pratviel \& J. Wilbert, p. 28.

Barrère P. 1746. Observations sur l'origine et la formation des pierres figurées, et sur celles qui, tant extérieurement qu'intérieurement, ont une figure régulière $\&$ déterminée. Paris : d'Houry, 67 p. + pl.

Borda [d'Oro] J-F. 1798. Mémoires sur les Fossiles des environs de Dax. Journal général de la Littérature de France $1^{\text {re }}$ année (vendémiaire an VII): 313-315; Magasin encyclopédique ou Journal des Sciences, des Lettres et des Arts 4 année: 419-420; Journal typographique et bibliographique an VII: 88 (annonce de la parution de l'ouvrage en 3 volumes in $-4^{\circ}$ et 64 planches).

Borda d'Oro J-F. 1879-1881. Mémoires pour servir à l'histoire des fossiles des environs de Dax en Gascogne. Bulletin de la Société Borda $4^{\mathrm{e}}$ année: $25-36,81-92 ; 5^{\mathrm{e}}$ année: 1-11, 51-64, 141-149; $6^{\mathrm{e}}$ année: 301-307 (publication posthume très partielle).

Buffon G-L. (Leclerc de). 1749. Théorie de la Terre. In : G.-L. Leclerc de Buffon, ed. Histoire naturelle, générale et particulière, avec la description $d u$ Cabinet $d u$ Roy. Paris : Imprimerie royale, vol. 1.

Climens R de. 1884. Contrat passé entre Pierre de Lancre, conseiller au parlement, et Pierre de Lacourt, libraire, pour l'impression à quarante exemplaires de trois traités sur l'incrédulité ou mécréance du sortilège. Archives historiques de la Gironde XXIV : 176-177.

Colonna F. 1616. De Glossopetris Dissertatio. In: Colonna F, ed. Fabii Columnae, [..] Purpura, hoc est de purpura ab animali testaceo fusa, de hoc ipso animali, aliisque rarioribus testaceis quibusdam [..]. Romae: apud J. Mascardum, pp. 31-39.

Communay A. 1890. Le conseiller Pierre de Lancre. Agen: Veuve Lamy, $66 \mathrm{p}$.

Coste P. 1908. Jacques-François de Borda d'Oro. Bulletin de la Société Borda $33^{\mathrm{e}}$ année: $319-335$.

Courteault P. 1909. La paléontologie et la préhistoire à l'Académie de Bordeaux au XVIII ${ }^{\mathrm{e}}$ siècle. Revue des études anciennes 11: 166-168.

Dezallier d'Argenville A-J. 1751. Enumerationis fossilium, quae in omnibus Galliae provinciis reperiuntur, tentamina. Paris : apud J. de Bure, $134 \mathrm{p}$.

Desmarest N, Doin G-T, Ferry C-J, Huot J-J-N, Bory de Saint-Vincent J-B-G-M. An III-1828. Encyclopédie méthodique. Géographiephysique. Paris : H. Agasse, 5 vol. + atlas.

Dubreuilh J, Karnay G. 1994. Carte géologique de la France (1/50 000), feuille Sainte-Foy-la-Grande (805). Orléans : BRGM, 1 feuille en couleurs, $60 \times 90 \mathrm{~cm}$ et notice explicative par $\mathrm{J}$. Dubreuilh, avec la collaboration de F. Charney, 1994, 52 p.

Ellenberger F. 1988. Histoire de la géologie. Tome 1, Des Anciens à la première moitié du XVII ${ }^{\mathrm{e}}$ siècle. Paris : Lavoisier, $352 \mathrm{p}$.

Fallot E. 1887. Compte rendu géologique de la $2^{\mathrm{e}}$ excursion géologique trimestrielle faite le 8 mars 1887 à Sainte-Foy-laGrande. Procès-verbaux de la Société linnéenne de Bordeaux 41: liii-lviii.

Français J. 1910. L’Église et la sorcellerie; précis historique suivi des documents officiels, des textes principaux et d'un procès inédit. Paris : Librairie critique, $272 \mathrm{p}$.

Gaffarel J. 1629. Curiositez inouyes sur la sculpture talismanique des Persans, horoscope des patriarches et lecture des estoilles. Paris : H. Du Mesnil, 644 p.

Gassend P. 1658. De Lapidibus, ac mettalis (Phisicae Sectio III, Liber III). In: Gassend P, ed. Opera Omnia [..]. Lyon: Anisson et Devenet, t. 2, pp. 112-122.
Gaudant J. 2008. Les fossiles témoins du déluge; Johann Jakob Scheuchzer; (présenté par) Jean Gaudant; deux traductions (du latin) de Geneviève Bouillet. Paris: Mines Paris-tech, 163 p.

Gobet N. 1779. Mémoire sur les différentes espèces de mines qui ont été \& sont encore exploitées en Gascogne. In: Gobet N, ed. Les anciens minéralogistes du royaume de France: avec des notes. Paris : Ruault, vol. 1, pp. 232-248.

Godard G. 2005. Peiresc et la proto-géologie du début du XVII ${ }^{\mathrm{e}}$ siècle. Sciences et Techniques en Perspective 9( $2^{\mathrm{e}}$ série): 63-110.

Godard G. 2014. Le Discours sur les coquilles de mer qu'on trouve en terre ferme, particulièrement en Champagne, adressé par le jésuite Jacques Vignier à Peiresc en 1635 : entre Déluge et «inondation » de la mer. Travaux du Comité français d'Histoire de la Géologie (COFRHIGEO) XXVIII( $3^{\mathrm{e}}$ série): 157-173.

Godard G. 2017. The Discourse on the seashells [..., found] in Champagne, written by Vignier to Peiresc (1635): An early text supporting the organic origin of fossils. Comptes Rendus Palevol 16: $122-131$.

Godard G. 2018. Premières descriptions des faluns miocènes de Sainte-Croix-du-Mont en Guyenne $(1622,1718)$ : Pierre de L'Ancre a-t-il perçu le principe de superposition 45 ans avant Sténon? Bulletin de la Société Linnéenne de Bordeaux: sous presse.

Guettard J.É. 1759. Mémoire sur les accidents des coquilles fossiles, comparés à ceux qui arrivent aux coquilles qu'on trouve maintenant dans la mer. Histoire de l'Académie royale des Sciences [..] avec les mémoires [..] tirés des registres de cette Académie 1759: 189-226, pl. i-iv ; 329-357, pl. i-iii ; 399-419, pl. i-ii.

Hooykaas R. 1963. Natural law and divine miracle: Principle of uniformity in geology, biology, and theology. Leiden: E. J. Brill, XVIII-237 p.

Laboulais-Lesage I. 2006. Les géographies de l'Encyclopédie méthodique. In: Blanckaert $\mathrm{C}$, Porret $\mathrm{M}$, ed. L'Encyclopédie méthodique (1782-1832) : des Lumières au positivisme. Genève : Droz, pp. 185-211.

L'Ancre P de. 1612. Tableau de l'inconstance des mauuais anges et demons, ou il est amplement traicté des Sorciers \& de la Sorcellerie [... Paris : J. Berjon, in-4 $4^{\circ}$, [XXXIV]-569-[XXVI] p.

L'Ancre $P$ de. 1617. Le Livre des princes, contenant plusieurs notables discours, pour l'instruction des roys, empereurs et monarques. Paris : N. Buon, in $-4^{\circ}$, pièces liminaires, $807 \mathrm{p}$, table.

L'Ancre $P$ de. 1622. L'incredulité et mescreance du sortilege plainement conuaincue, ou il est amplement et curieusement traicté, de la verité ou Illusion du Sortilege [..] : Et d'vne infinité d'autres rares \& nouueaux subjects. Paris: Nicolas Buon, in-4 ${ }^{\circ}, 52-841$ p. http://gallica.bnf.fr/ark:/12148/bpt6k763251.

L'Ancre P de. 1627. Du sortilege. Ou il est traicté, s'il est plus expedient de supprimer et tenir soubs silence les abominations \& malefices des sorciers, que les publier \& manifester [..]. Bergerac : Vernoy, in $-4^{\circ}, 340$ (330) $\mathrm{p}$.

Le Mao C. 2007. Parlement et parlementaires : Bordeaux au Grand siècle. Champ Vallon: Seyssel, 378 p.

Lesport J-F, Cluzaud A, Verhecken A. 2012. Les publications du Docteur Jean-Pierre Sylvestre de Grateloup sur les mollusques fossiles du Bassin d'Aquitaine (S.-O. France) : dates de parutions et commentaires. Bulletin de la Société linnéenne de Bordeaux 147 ; (nouv. série), $\mathrm{n}^{\circ}$ 40: 417-485.

Lyell C. 1830-1833. Principles of geology [. .]. London: John Murray, 3 vol.

Muteau C, Garnier J. 1858-1860. Galerie bourguignonne. Dijon: J. Picard, 3 vol. 
Odin GS. 2004. Le catalogue du cabinet de curiosités de JacquesFrançois Borda d'Oro (1718-1804), bicentenaire d'une collection régionale de roches et de fossiles. Travaux du Comité français d'Histoire de la Géologie (COFRHIGEO) 18( $3^{\mathrm{e}}$ série): 1-48.

Odin GS. 2005. Sur un manuscrit inédit de Jacques-François Borda d'Oro (1718-1804) : contribution d'un amateur de géologie des environs de Dax (Landes). Comptes Rendus Palevol 4: 436-451.

Odin GS, Zubillaga I. 2005. Les fossiles du Cabinet de curiosités géologiques de Jacques-François Borda d'Oro, collectionneur Landais (1718-1804). Cossmanniana: bulletin du groupe d'étude et de recherche macrofaune cénozoique 10: 81-94.

Orbigny A d'. 1840-1867. Paléontologie française. Description zoologique et géologique de tous les animaux mollusques et rayonnés fossiles de la France.. ( $1^{\text {re }}$ édition). Paris : 1'auteur, puis Bertrand A, Masson V, I-VIII vol. + atlas de pl. in $-8^{\circ}$.

Palissy B. 1580. Discours admirables de la nature des eaux et fontaines, tant naturelles qu'artificielles, des métaux, des sels et salines, des pierres, des terres, du feu et des émaux [..]. Paris : Martin le jeune, XIII-361 p.

Petit-Lafitte A. 1846. Paléontologie ou des Lois de l'organisation des êtres vivants, par Marcel de Serres. L'Agriculture, comme source de richesse, comme garantie du repos social [...] $7^{\mathrm{e}}$ année: 273-278.

Petit-Lafitte A. 1867. Une excursion agricole dans les prairies naturelles de Sainte-Croix-du-Mont et jusqu'à la chapelle monolithe du château de Loubens (dimanche 26 mai 1867). Bordeaux : E. Bissei, 15 p.

Platel J-P. 1992. Carte géologique de la France à $1 / 50000$, feuille Belin (850). Orléans : BRGM, 1 feuille en couleurs, $60 \times 90 \mathrm{~cm}$ et notice explicative par J.P. Platel, 1992, 66 p.

Plaziat J-C. 2011. Bernard Palissy (1510-1590) and the French geologists: a critical reappraisal concerning the founding naturalist and his rustic ceramics. Bulletin de la Société géologique de France 182: 255-267.

Puy J du. 1601. La recherche et descouverte des mines des montagnes Pyrénées, faicte en l'an mil six cens, par Jean de Malus, rédigée en escrit par M. Jean du Puy. Bourdeaus : S. Millanges, in-12, 110 p. (+ Ms 559, Bibliothèque municipale de Bordeaux, 1600).

Rudwick MJS. 1972. The meaning of fossils: episodes in the history of palaeontology ( $1^{\text {st }}$ edition). New York: Macdonald and Co., $287 \mathrm{p}$.

Scheuchzer JJ. 1708. Piscium querelae et vindiciae expositae a Johanne Jacobo Scheuchzero, [...]. Tiguri : sumt. authoris, in $-4^{\circ}$, IV-36 p., pl.

Steensen N. 1667. Canis carchariae dissectum caput. In : Steensen N, ed. Nicolai Stenonis Elementorum myologiae specimen, seu Musculi descriptio geometrica, cui accedunt canis carchariae dissectum caput et dissectus piscis ex canum genere ad serenissimum Ferdinandum II magnum Etruriae ducem. Florentiae: ex typ. sub signo Stellae, VI-123 p., VII pl.

Steensen N. 1669. Nicolai Stenonis de Solido intra solidum naturaliter contento dissertationis prodromus [..]. Florentiae : ex typ. sub signo Stellae, in $-4^{\circ}$, (2), 78, (1) p., (1) f. de pl. dépl.

Taylor KL. 1969. Nicolas Desmarest and geology in the eighteenth century. In: Schneer CJ, ed. Toward a history of geology. Cambridge, Mass., London: M.I.T. Press, pp. 339-356.

Taylor KL. 1997. La genèse d'un naturaliste: Desmarest, la lecture et la nature. In: Gohau G, ed. De la géologie à son histoire, ouvrage édité en l'honneur de François Ellenberger. Paris: C.T.H.S., pp. 61-74.

Woodward J. 1695. An Essay toward a natural history of the Earth and terrestrial bodies, especially minerals; as also of the sea, rivers and springs, with an account of the universal deluge and of the effects that it had upon the Earth. London: R. Wilkin, in $-4^{\circ}$, pièces liminaires, 277(-2) p.

\section{Appendix : sources}

All sources are in French and are presented below in their original language. The manuscripts of the Académie royale des Sciences, belles-lettres et arts de Bordeaux (AB), stored at the Bibliothèque municipale de Bordeaux (BMB), are available online at the following link: http://bibliotheque.bordeaux.fr/in/ faces/imageReader.xhtml?id=h::BordeauxS_B330636101_*, where $*$ is specified below in the references.

\section{A1 - Description des faluns de Sainte- Croix-du-Mont par Pierre de L’Ancre (1622)}

La version intégrale de L'incredulité et mescreance du sortilège plainement conuaincue (L'Ancre, 1622) est disponible dans Gallica (http://gallica.bnf.fr/ark:/12148/bpt6k763251). On y consultera les Advertissemens (p. 17-42), dont des extraits ont été annotés et commentés par Godard (2018).

\section{A2 - «Reflections sommaires sur quelques pierres de la Terre de Sales " (entre 1631 et 1673)}

Bibliothèque nationale de France, Arsenal, ms. fr. 2890, $126 \mathrm{~S}$. A.F., $59^{\mathrm{e}}$ manuscrit du "portefeuille LXIII de Philibert de la Marre, tome $1 »$, ff. 404r-405r. Transcription et annotation: Online supplementary material SM4 in Godard (2017).

\section{A3 - Mémoires sur les faluns de Sainte- Croix-du-Mont (1718)}

A3.1 Sur les coquilles d'huîtres de Sainte-Croix du Mont, par l'abbé Jules Bellet, lu le 8 mai 1718; AB, BMB, ms 828/017 $\left(\mathrm{n}^{\circ} 5\right), 16$ p. $\left(*=\mathrm{Ms} 828 \_017 \_005\right)$.

A3.2 Mémoire touchant les coquillages de $S^{\text {te }}$ Croix du Mont, par Isaac Sarrau de Boynet, lu le 25 août 1718 ; AB, BMB, ms 828/002 (n6), 24 p. (*=Ms828_002_006).

A3.3 Mémoire sur les coquillages de $S^{\text {te }}$ Croix du Mont, par Sarrau de Boynet, 25 août 1718; AB, BMB, ms 828/016 $\left(n^{\circ} 24\right), 12$ p. (*=Ms828_016_024).

A3.4 Résomption de la dissertation de M. de Sarrau sur les coquillages de $S^{\text {te }}$ Croix du Mont, par Montesquieu; AB, BMB, ms 828/006 (n 7), 1 p. (*=Ms828_006_007_004).

A3.5 Vüe de la Coste de $S^{\text {te }}$ Croix du mont, Bibliothèque de l'Institut, Paris, ms 2721/51, plan en couleurs de 51,5 cm $\times 53,5 \mathrm{~cm}$ à l'échelle de $9,4 \mathrm{~cm}$ pour 100 toises ( $c a$. 1:2100), avec profil topographique de la Garonne à Loubens (Fig. 6).

Les mémoires de Sarrau de Boynet (A3.2 et A3.3) sont comparables et portent tous deux la date du 25 août 1718. Le second, plus soigné que le premier, semble être une copie plus récente car il adopte une graphie assez moderne. Il y est noté en marge: «Réservé pour la collection, quant à la partie 
descriptive seulement, dans le comité du 14 juin 1785 ». La carte conservée à l'Institut (A3.5; Fig. 6) pourrait avoir été levée par Barrelier de Bitry et devait être accompagnée d'une autre version du mémoire de l'abbé Bellet ( $c f$. texte).

\section{A4 - Mémoires sur les faluns des environs de Sainte-Foy-la-Grande (1736)}

A4.1 Voyage littéraire à Sainte-Foy..., par l'abbé Jules Bellet, 1736; AB, BMB, ms 828/017 (n 7), 20 p. (* = Ms828_017 007). Texte original des citations ( $c f$. texte) : « dans la paroisse du Fleix, sur le coteau de la Nogarède, on a trouvé une quantité prodigieuse d'écailles d'huitres, parmi des couches de pierre molle d'environ 4 à 5 pouces d'épaisseur. Dans quelques morceaux d'un rocher qui s'écroule dans la rivière de Dordogne, on voit des petoncles pétrifiées et dans quelques autres quelques empreintes de quelques autres coquilles ». «Dans la paroisse de Monfaucon voisine de celle du Fleix, au lieu nommé Barbeyrole, on a ouvert une carriere de pierre dure, de laquelle on ne détache pas une pierre qu'on n'y trouve une corne d'Ammon, dont la base est attachée a la pierre, avec des écailles d'huitres petrifiées qui ont encore leur nacre. On a trouvé aussi des coquillages petrifiés avec leurs couleurs naturelles ».

A4.2 Observations d'histoire naturelle extraites des voyages littéraires de M. l'abbé Bellet, par Sarrau de Boynet, 1736; AB, BMB, ms 828/016 (n¹4), 12 p. (*=Ms828_016_014).

\section{A5 - Mémoires manuscrits de Jacques François de Borda d'Oro, sur la géologie des environs de Dax en Gascogne}

A5.1 Lettre de M. de Borda (d'Oro) à M. de **** contenant des observations d'histoire naturelle dans la paroisse de Sorde, canton de Dax, «à Dax, le 20 août 1745 »; AB, BMB, ms 828/026 (006), 16 p. (*= Ms828_026_006) (sur les nummulites de Sorde-l'Abbaye).

A5.2 Mémoire sur les habitations d'animaux marins trouvées dans une carrière des environs de Dax, lu le 21 juin 1767 ; AB, $\mathrm{BMB}, \mathrm{ms} 828 / 026$ (007), 30 p. (* = Ms828_026_007) (sur des fossiles de Montfort-en-Chalosse).

A5.3 Mémoire sur l'analyse des eaux minérales, lu le 25 août 1768 ; AB, BMB, ms 828/026 (009), 16 p. (*= Ms828_ 026_009).

A5.4 Observations minéralogiques faites sur la côte de l'extrémité méridionale de la Gascogne et sur celle du pays des Basques, «envoié au mois d'aout 1778 »; AB, BMB, ms 828/ 026 (010), 26 p. $(*=$ Ms828 026 010) (description des terrains tertiaires et crétacés et $\overline{\text { de }}$ leurs fossiles).

A5.5 Mémoires pour servir l'histoire du règne minéral aux environs de Dax en Gascogne, Mémoires sur les fossiles des environs de Dax (fin du $18^{\mathrm{e}}$ siècle), Bibliothèque de la Société de Borda, Dax, 3 vol., 595 p +599 p. +285 p.; publication posthume très partielle (Borda d'Oro, 1879-1881) disponible dans Gallica (http://gallica.bnf.fr/ark:/12148/ cb34376184g/date).

\section{A6 - Mémoires manuscrits de l'Académie de Bordeaux sur les "pierres figurées"}

A6.1 Mémoires attribuables à Pierre Barrère, présentés pour les concours de dissertation sur les pierres figurées de 1743 et 1745 :

- Recherches physiques sur l'origine et la formation des pierres figurées, 1743 ; BMB, ms 828/067 (006), 32 p. dont 14 numérotées $\left(*=\mathrm{Ms} 828 \_067\right.$ 006);

- Origine et formation des pierres figurées: Dissertation physique, « examinée et rejettée du concours le 2 mai (1745)»; BMB, ms 828/068 (007), 36 p. (*=Ms828_068_007);

- Sur l'origine et la formation des pierres figurées, etc., 1745; BMB, ms 828/069 (001), 40 p. dont 2 pl. (* = Ms828_069_001);

- Recherches physiques sur l'origine et la formation des pierres qui tant interieurement qu'exterieurement ont une figure regulière et déterminée, "retenue le 23 may 1745 »; BMB, ms 828/069 (002), 26 p. (*= Ms828_069_002);

- Recherche comment les corps terrestres et marins qui se trouvent dans la terre s'y sont pétrifiés, 1745 ; BMB, ms 828/069 (003), p. 27-30 (*= Ms828_069_003) (ce semble un fragment).

- Le troisième mémoire est une version manuscrite de l'ouvrage de Pierre Barrère (1746). Les autres s'en approchent par le style, certaines expressions et observations, en particulier sur le Roussillon. Le quatrième, de 1745 , est une nouvelle version du premier, de 1743, dans laquelle l'auteur a introduit des idées uniformitaristes (p. 6, 17, 18).

A6.2 Autres mémoires présentés pour les concours de dissertation sur les pierres figurées de 1743 et 1745 :

- Lettre sur les pierres figurées, par «S.A.D.L.», à «B... (Bordeaux?) ce 2 avril $1743 »$; BMB, ms 828/020 (050), 4 p. $(*=$ Ms828_020_050).

- Dissertation sur l'origine et la cause des pierres figurées, «par Jean Pierre Perey, ministre de l'église de Pomi dans le Balliage d'Yverdon au canton de Berne en Suisse », 1743 (?); BMB, ms 828/031, 140 p. (*=Ms828_031).

- Dissertation sur l'origine et la cause des pierres figurées, avec figures, 1743 ; BMB, ms 828/066 (008), 36 p. + 1 pl. (* = Ms828 066 008).

- De naturâ et efformatione lapidum figuratorum dissertatio, « examinée et rejettée du concours, le 4 aout (1743)»; BMB, ms 828/067 (004), 24 p. (*=Ms828_067_004).

- Dissertation sur l'origine et la formation des pierres figurées, «rejettée du concours, le 4 aout (1743)»; BMB, ms 828/067 (005), 30 p. (*=Ms828_067_005).

- De lapidum formatione et de origine et formatione lapidum figuratorum, par «Jean-Pierre Süssmilch, conseiller du consistoire de sa majesté le roi de Prusse, etc., à Berlin », 1745 ; BMB, ms 828/068 (005), 40 p. $\quad(*=\mathrm{Ms} 828$ 068_005). 
- Dissertations sur l'origine et la formation des pierres figurées, «parvenue le 9 mars 1745 »; BMB, ms 828/068 (006), 52 p. (*= Ms828_068_006).

- Critiques de la distributioñ des prix et du jugement de l'Académie, à propos des pierres figurées, par «A F. (Filhot?) ce $87^{\text {bre }} 1745 »$; BMB, ms 828/020 (054), 4 p. $\quad(*=$ Ms828_020_054) (ajout au crayon "Chimbaud de Filhot?», qui était écuyer et avocat au parlement de Bordeaux).

A6.3 Autres mémoires sur les pierres figurées :

- [Rapport sur des ossements fossiles trouvés dans la paroisse de Haux, dans l'Entre-deux-Mers], par Sarrau de Vésis, lu le $1^{\mathrm{er}}$ mai 1719; BMB, ms 828/001 (004), 10 p. (*=Ms828_001_004).

- Réflexions sur l'histoire naturelle de la province de Guyenne, suivies d'un catalogue des fossiles de cette province et la Gascogne, du Quercy, de la Bigorre, du Périgord, du Rouergue, de l'Armagnac, de la Saintonge et de l'Angoumois, «Discours prononcé par le Président Barbot à la rentrée de l'académie, le 16 janvier 1739 »; BMB, ms 828/104 (018), 28 p. (*=Ms828_104_018).

- Essai sur l'origine des bélemnites, par R.P. Merle, lu le 13 juillet 1766; BMB, ms 828/013 (019), 22 p. (* = Ms828 013 019).

- Observations sur la génération des fossiles, par R.P. Merle, 11 février 1767 ; lu à la séance du 26 mars; $\mathrm{BMB}, \mathrm{ms} 828$ / 013 (020), 24 p. (* = Ms828_013_020).

- [Charbon de terre et minerai de cuivre ; pétrifications dans le Périgord...], par Salviat, "Brive le 2 aoust 1776»; BMB, ms 828/021 (053), 2 p. (* = Ms828_021_053).

\section{A7 - Mémoires de Nicolas Desmarest (1761, an III-1809)}

A7.1 Voyage dans une partie du Bordelois et du Périgord, suivi d'une Tournée $d u$ Bazadois, $d u$ Condomois et d'Agenois, commencée le 27 octobre 1761; BMB, ms 0721, 317 p. +40 f. (*=Ms721). Ces mémoires sont anonymes, mais il est clair qu'ils ont été rédigés par Nicolas Desmarest alors que celui-ci accompagnait l'intendant de Bordeaux, Boutin de La Coulommière (Taylor, 1997). Il y est question de géologie, d'agriculture et d'administration des environs de Bordeaux, Libourne, Périgueux puis de la vallée de la Garonne entre Bordeaux et Agen. Le premier mémoire est riche en observations géologiques : e.g., p. 5, description de «madrépores »; p. 65, côteaux de la Dordogne, près de Libourne; p. 112-119, 124-134, les faluns de Saint-Emilion, leurs fossiles et leur exploitation; géologie des environs de Montagne (p. 141-147), de Libourne (p. 154-157, 171-173), puis au-delà de Mussidan vers Périgueux (p. 217-219, 237240, 289-293); description des fossiles marins silicifiés de Chancelade («madrépores», «dentales», «poulettes» [térébratules], « lames», " peignes », etc. : p. 306-316)... Le second mémoire est moins géologique; Desmarest y mentionne les «pierres aux huitres de Sainte-Croix».

A7.2 Desmarest a reproduit des observations des mémoires précédents, complétées par d'autres études faites en Aquitaine en 1764, 1769 et 1771, dans son Encyclopédie méthodique (Desmarest et al., an III-1828) : e.g., vol. 1, p. 418; vol. 2, p. 296 (article allios), p. 349-351 (amas de coquilles), p. 483 (ammites), p. 610-635 (Angoumois); vol. 3, p. 17-18 (Bordeaux), p. 585-587 (Dax).

Cite this article as: Godard G. 2018. Early texts on the Cenozoic fossils of Aquitaine (1622-1767) and pioneering debates on the organic origin of fossils, the superpositioning of strata and the mobility of the seas, BSGF - Earth Sciences Bulletin 189: 8. 